\title{
Reasons for students' poor Clinical competencies in the Primary Health Care: Clinical nursing, diagnosis treatment AND CARE PROGRAMME
}

Authors:

Nomasonto B.D. Magobe ${ }^{1}$

Sonya Beukes ${ }^{1}$

Ann Müller ${ }^{1}$

\section{Affiliations:}

${ }^{1}$ Nursing Department, University of Johannesburg, South Africa

Correspondence to:

Nomasonto Magobe

email:

nmagobe@uj.ac.za

Postal address:

Department of Nursing, PO Box 524, Auckland Park 2006, South Africa

\section{Keywords:}

Clinical guidelines; clinical learning programme; clinical preceptor or instructor; primary clinical nurse (PCNs); service package

\section{Dates:}

Received: 03 Dec. 2009

Accepted: 04 Aug. 2010

Published: 25 Nov. 2010

How to cite this article: Magobe, N.B.D., Beukes, S., Müller, A., 2010, 'Reasons for students' poor clinical competencies in the Primary Health Care: Clinical nursing, diagnosis treatment and care programme', Health SA Gesondheid 15(1), Art. \#525, 6 pages. DOI: 10.4102 / hsag.v15i1.525

This article is available at:

http://www.hsag.co.za

\section{(c) 2010. The Authors.} Licensee: OpenJournals Publishing. This work is licensed under the Creative Commons Attribution License.

\section{ABSTRACT}

'No member of [health] staff should undertake tasks unless they are competent to do so' is stated in the Comprehensive Primary Health Care Service Package for South Africa (Department of Health 2001) document. In South Africa, primary clinical nurses (PCNs), traditionally known as primary health care nurses (PHCNs), function as 'frontline providers' of clinical primary health care (PHC) services within public PHC facilities, which is their extended role. This extended role of registered nurses (set out in section 38A of the Nursing Act 50 of 1978, as amended) demands high clinical competency training by nursing schools and universities.

The objectives of the study were to explore and describe the perceptions of both clinical instructors and students, in terms of the reasons for poor clinical competencies. Results established that two main challenges contributed to students' poor clinical competencies: challenges within the PHC clinical field and challenges within the learning programme (University).

\section{OPSOMMING}

Die primêre kliniese verpleegkundiges, tradisioneel bekend as primêre gesondheidsorg verpleegkundiges, funksioneer in Suid-Afrika as eerste-linie verskaffers van kliniese primêre gesondheidsorg (PGS) dienste binne die publieke PGS fasiliteite. Dit is hulle uitgebreide rol. Hierdie uitgebreide rol van die verpleegkundige (soos deur Wet op Verpleging, No 50 van 1978, artikel 38A voorgeskryf), vereis opleiding in kliniese vaardighede van hoë gehalte deur verpleegskole en universiteite.

Die doelwitte van die navorsing was om die persepsies van beide kliniese dosente en leerders, met betrekking tot die redes vir swak kliniese vaardighede, repektiewelik te verken en te beskryf. Twee temas is deur die resultate as uitdagings (hoof redes) vir die swak vaardighede van leerders aangetoon, naamlik uitdagings in die PGS kliniese praktyk en die uitdagings in die leerprogram (universiteit).

\section{INTRODUCTION}

\section{Background and rationale}

The World Health Organization (WHO) advocates, and has declared, primary health care (PHC) as a global concept approach (WHO 1978: declaration VIII). One of the WHO's concepts of PHC is promoted as 'essential health care addressing the main health problems in the community, including the provision of appropriate treatment of common diseases and injuries and providing essential drugs' (WHO 1978). The WHO has further stated that

all governments should formulate national policies, strategies and plans of action to launch and sustain PHC as part of a comprehensive national health system and in coordination with other sectors.

(WHO 1978: declaration VIII)

In 1996, the South African Department of Health (DoH) formulated a health policy document entitled Restructuring the National Health System for Universal Primary Health Care, in which it is stated that a specialised group of registered nurses (PCNs), traditionally known as primary health care nurses (PHCNs), are expected to function independently as frontline providers of clinical PHC services within public health facilities (Department of Health 1996:18).

This entails, amongst other clinical activities, the following:

$[T o]$ examine every patient that reports to the $[\mathrm{PHC}]$ clinic, [the PCN] treats and discharges those patients that she is able to treat. If she cannot make a diagnosis, or cannot treat a patient, she refers the patient to the doctor in the team who is the leader, the manager and consultant of the [PHC] team.

(Beukes 1983:6; Department of Health 2001:23)

This position is regarded as an extended role of the registered nurse and is recognised and regulated by the South African Nursing Council (SANC) through the Nursing Act, No. 50 of 1978.

To execute such clinical functions, the DoHemphasises theneed for competency in all health workers in the Comprehensive Primary Health Care Service Packagefor South Africa (Department of Health 2001): 'no member of staff (including PCNs) should undertake tasks unless they are competent to do so'. This is supported by another DoH policy document entitled South African Health Sector Strategic Framework of 1999-2004 (Department of Health 1999:17) which maintains that 'appropriately trained PHC nurses must be available in all public PHC facilities.' 
To ensure the comprehensive training of $\mathrm{PHC}$ nurses, a university in Gauteng, where the study was conducted, provides a learning programme as a qualification for a post-basic diploma at National Qualifications Framework (NQF) level 7: PHC: Clinical Nursing, Diagnosis, Treatment and Care. The course equips registered nurses with clinical knowledge, skills, attitudes and values in patient assessment, diagnosis, treatment and care, incorporating clinical competencies such as the prescribing and issuing of Schedule 1-4 drugs in the PHC essential drug list (EDL), (Department of Health 1996:17; South African National Council 1984:R 2148). The SANC is a statutory body entrusted to set and maintain standards of nursing education and practice in South Africa (South Africa 1978). This university course meets the SANC criteria required (South African Nursing Council 1997) for a suitable post-basic learning programme and has also been accepted by the South African Qualifications Authority (SAQA).

The programme's strategies include clinical guidance by lecturers, clinical instructors and preceptors, because personal experience and clinical exercises engender successful outcomes during the clinical learning phase and ensure internalisation of the clinical content and skill (Bezuidenhout 2003:19). Such training enables students to 'function independently, with more limited referral to [a] medical practitioner' (Beukes 1983:6; DoH 1996:18; DoH 2001:23) within public PHC facilities. It aims at producing PCNs who are both clinically competent and prepared for clinical practice (Edwards et al. 2004).

The researcher observed that despite the clinical supervision of lecturers, clinical instructors and preceptors, students displayed poor clinical competencies at the end of the learning programme. Law (2000) is of the opinion that the 'ultimate issues of quality in teaching and learning may be addressed by the teacher's commitment as reflective practitioner.' Other studies also show that shortcomings exist in clinical practice and that PCNs exhibit poor clinical competencies (Kyrkjebo \& Hage 2004; Monamodi 1998:69), which can lead to erroneous health assessment and management of patients (Mofukeng 1998:63-64).

\section{PROBLEM STATEMENT AND RESEARCH QUESTION}

In the learning programme, despite providing clinical supervision, guidance and support by lecturers, clinical instructors and preceptors to help foster successful clinical outcomes and internalisation of clinical content and skill (Bezuidenhout 2003:19), students have nevertheless displayed poor clinical competencies at the end of the course. The question arose, therefore, as to why this is the case.

\section{RESEARCH PURPOSE AND OBJECTIVES}

This paper reports on the reasons for poor clinical competencies of students following the PHC: Clinical Nursing, Diagnosis, Treatment and Care programme provided at a university in Gauteng, South Africa. The objectives of the study were to explore and describe the perceptions of clinical instructors and students' in terms of the reasons for students poor clinical competencies.

\section{Definition of key concepts \\ Clinical competence}

Within the context of this study, clinical competencies refer to further development of knowledge, skills, attitudes and values of students following the PHC: Clinical Assessment, Diagnosis, Treatment and Care programme, in order to promote the health of individuals, groups and communities (Muller 1998, in Morolong 2002:8; RAU 2002:5; South African Qualifications Authority 2000:16). The clinical competencies further incorporate the prescribing and issuing of essential drugs included in the
PHC EDL for Schedule 1-4 drugs only (Department of Health 1996:17; South African Nursing Council 1984:R2148).

\section{Learning programme}

The PHC: Clinical Nursing, Diagnosis, Treatment and Care qualification learning programme is a specific course offered to students which will enable them to meet the requirements for working in a PHC (South African Qualifications Authority 2000:9). This qualification is offered as a post-basic course at National Qualifications Framework (NQF) level 7 and aims to educate and train registered nurses in the clinical competencies described above.

\section{Students}

The term 'students' refers to the class of 2003, and previous or future students in the course, who are professional nurses and are registered for the programme PHC: Clinical Nursing, Diagnosis, Treatment and Care course at the university where the study took place.

\section{Primary clinical nurse}

The abbreviation PCN (primary clinical nurse) refers to registered nurses (traditionally known as PHCN) who have the additional post-basic qualification of Diploma in Clinical Nursing Science, Health Assessment, Treatment and Care as recognised by the SANC. Students in the programme under review qualify to be a PCN after successful completion.

\section{Clinical instructor}

Within the context of this study, the clinical instructor is a qualified PCN and acts as clinical teacher and tutor to students. Clinical instructors facilitate the learning process and ensure that clinical learning takes place (Morton-Cooper \& Palmer 2000:197).

\section{PHC clinic/facility; health clinic; Primary Health Care environment/clinical field}

PHC clinic/facility/environment/clinical field in the context of the study refers to a fixed or mobile health service rendering comprehensive PHC services, and is situated within the community it is serving. This includes the general practitioners' consulting rooms within the community. The students practise and learn their clinical skills in these facilities under the supervision of clinical instructors and preceptors.

\section{RESEARCH METHOD AND DESIGN}

A qualitative, exploratory, descriptive and contextual design (Creswell 1994:184; De Vos 2001:261; Creswell 2003:208) was employed within the context of the PHC: Clinical Nursing, Diagnosis, Treatment and Care course at the university where the study was conducted.

\section{Sampling of clinical instructors}

A purposive convenience sample of all consenting clinical instructors $(n=6)$ was used (Polit \& Hungler 1995:638) because 'individuals known to have the desired and similar expertise may be sought in purposive sampling' (Burns \& Grove 2001:425). The inclusion criterion was that the participants were the same clinical instructors involved in the students' clinical supervision and guidance; they would be able to provide rich data to help increase theoretical understanding of the reasons underlying students' poor clinical competencies (Burns \& Grove 2001:367).

\section{Sampling of students}

A convenience sampling approach included all consenting students $(n=34)$ who were registered for the programme in the academic year 2003 (Polit \& Hungler 1995:638). The criteria for inclusion were that the students were active and attended clinical contact sessions, as required by the learning programme (RAU 2002). 


\section{Data collection}

Data were collected from clinical instructors $(n=6)$ and students $(n=34)$ using audiotaped focus group interviews (Burns \& Grove 2001:424-426; De Vos 2001:320-324). Clinical instructors were interviewed in one focus group and students in four separate focus groups, concentrating specifically on the reasons for students' poor clinical competencies. Interviewing groups, that are similar to each other in experience and characteristics, facilitate open discussions (Burns \& Grove 2001:425).

The focus group interviews followed the process as described by De Vos (2001:316-320) in which a central question was posed:

'What do you think the reasons are for poor clinical competencies of students of this programme PHC: Clinical Nursing, Diagnosis, Treatment and Care?

\section{Data analysis}

Transcript data were assessed by the researcher and the external independent coder, using Tesch's data analysis method (1990) as described in Creswell (1994:155). Data from the focus group interviews of clinical instructors and students were transcribed independently and verified for integrity by the researcher. As the researcher was not involved in data collection, re-listening to the tapes and re-reading the transcripts helped also to familiarise the researcher with the raw data, referred to by Burns and Grove (2001:596) as 'dwelling with the data.'

\section{RESULTS}

The research findings for both clinical instructors and students were found to be similar, thus discussion of the results addresses the same themes and categories. Both the clinical instructors and students are referred to as research 'participants'. The primary challenge that emerged from the research findings is the lack of clinical practice by students in the PHC clinical practice field. Several reasons for this lack of clinical practice were expressed by participants during focus group interviews, and two major themes were established:

- Perceived challenges within the PHC clinical practice field (offered as reasons contributing to poor clinical competencies of students).

- Perceived challenges within the university's learning programme (offered as reasons contributing to students' poor clinical competencies).

For the purpose of this article, only challenges categorised under the first theme (theme 1: challenges within the PHC clinical practice field offered as reasons contributing to students' poor clinical competencies) are reported. These challenges are reflected in Table 1.

\section{ETHICAL CONSIDERATIONS}

The following ethical principles, according to the former Rand Afrikaans University (RAU) standards (RAU 2002), were adhered to throughout the study:
- the right to privacy, confidentiality and anonymity

- the right to equality, justice, human dignity and protection against harm

- the right to freedom of choice, expression and access to information

- an obligation to adhere to the practice of science.

\section{TRUSTWORTHINESS}

The research study applied Lincoln and Guba's method of trustworthiness (1985:290), the criteria for which are credibility (truth value), transferability (applicability), dependability (consistency) and conformability (neutrality).

\section{Credibility}

- The researcher has been engaged with the learning programme for more than 10 years and within the university for 5 years, and is therefore not 'a stranger in a strange world' (Lincoln \& Guba 1985:302).

- The focus group interviewer was an experienced researcher within the paradigm of qualitative research and thus was able to conduct the focus group interviews appropriately (Botes, in Rossouw 2000:196)

- Clinical instructors were PCN practitioners themselves and had been involved in this learning programme for 2 years and were therefore able to participate meaningfully in the study (Lincoln \& Guba 1985:302).

- The students who were interviewed and clinically evaluated were still students in the programme and were therefore able to identify and express those factors contributing to students' poor clinical competencies (Lincoln \& Guba 1985:302).

- The services of an external transcriber were used, whose transcripts were validated by the researcher through prolonged engagement (Botes, in Rossouw 2000:196).

- The external coder's findings were triangulated with the findings of the researcher and a consensus on themes and categories was reached.

\section{Transferability}

A thick description of the study facilitated possible transferability to similar contexts (De Vos 2001:349; Lincoln \& Guba 1985:316; Botes, in Rossouw 2000: 196).

\section{Dependability}

Several actions ensured dependability in this study:

- A dense description of the research methods and the appropriateness of the methodological applications were ensured (De Vos 2001:331, Lincoln \& Guba 1985:324).

- Data were accounted for through literature control and linkage to existing theoretical frameworks (Botes, in Rossouw 2000:196).

- All audiotaped focus group interviews were transcribed by an independent transcriber and the transcripts were validated by the researcher.

TABLE 1

Theme 1: Perceived challenges within the Primary Health Care (PHC) clinical practice field

\begin{tabular}{|c|c|c|}
\hline Themes & Major categories & Sub-catogories \\
\hline \multirow[t]{3}{*}{$\begin{array}{l}\text { Perceived challenges within the PHC clinical practice } \\
\text { field as reasons contributing to students' } \\
\text { poor clinical competencies }\end{array}$} & $\begin{array}{l}\text { - Lack of human and material resources in the PHC clinical } \\
\text { practice field }\end{array}$ & $\begin{array}{l}\text { - Shortage of staff } \\
\text { - Students regarded as part of staff (i.e. as workforce) } \\
\text { - Lack of clinical equipment and other relevant resources }\end{array}$ \\
\hline & - Staff burnout at the PHC clinical practice field & $\begin{array}{l}\text { - Low morale and negative attitude of preceptors and staff in } \\
\text { the PHC clinical field } \\
\text { - Lack of recognition, support and incentives for preceptors }\end{array}$ \\
\hline & - Lack of quality control in the PHC clinical practice field & $\begin{array}{l}\text { - Lack of continuing education for preceptors } \\
\text { - Lack of feedback from the preceptors and referral } \\
\text { resources } \\
\text { - Lack of appropriate qualifications by preceptors } \\
\text { - Lack of adequate staffing }\end{array}$ \\
\hline
\end{tabular}


- Involvement of an external independent coder in data analysis, triangulation of the findings with the researcher's findings and the continuous supervision by experienced senior research supervisors assisted in ensuring dependability.

\section{Confirmability}

Confirmability was achieved when credibility (truth value) and transferability (applicability) were established (Krefting (1990), in De Vos 2001:350) in the study, as explained above.

\section{DISCUSSION}

Theme 1: Perceived challenges within the Primary Health Care clinical practice field as reasons contributing to students' poor clinical competencies are discussed below.

Lack of human and material resources in the Primary Health Care clinical practice field

Shortage of staff

A shortage of staff in the PHC clinical practice field was perceived by participants as one of the reasons contributing to students' poor clinical competencies, as evidenced in statements such as:

'In the clinics there is lack of mentoring due to shortage of staff.'

"The mentors [preceptors] are [...] overloaded with work.

These findings are in keeping with Zondagh's observation (2004:20) that one of the major challenges faced by nurses in the South African health care system is the lack of provision of safe and adequate nurse staffing levels.

\section{Students regarded as part of staff or workforce}

These findings were confirmed in comments by student participants:

'Sometime I have to push the queue [consult patients in the queue] than to practise my skills as a student.'

'In the working situation, we don't have time to do exactly what we have been taught here because of the number of patients that we have to see.'

Similarly, Thwala (1999:47) found that students were looked upon as being part of the staff and/or as extra help in terms of the workload.

Lack of clinical equipment and other relevant resources One of the reasons for leaving the country, given by South African nurses who intended to work in other countries, was a lack of resources within the South African health care system (Ehlers et al. 2003:31).

'There is really shortage of resources ...we don't have Baumanometers in the clinics, and how are we suppose to work and be competent?

'There is lack of drugs and you end up learning bad treatment.'

Thwala (1999:41) also found that most of the clinical areas assigned to students lacked equipment which left staff (i.e. preceptors) with little energy to deal effectively with students (Nolan (1998), in Thwala 1999:41).

\section{Staff burnout in the Primary Health Care clinical practice field}

Clinical staff can easily experience burnout because of a shortage of staff, lack of equipment and/or the demands made by students (Cilliers 2003; Pulsford, Boit \& Owen 2002):

\section{'People in the clinics are stressed.'}

'One becomes burnt out later.'

Atkins and Williams (1995:1011) assert that preceptors (i.e. clinical staff) feel under pressure because their responsibilities towards students conflict with their responsibilities towards patients, management and colleagues.
Low morale and negative attitude of preceptors and staff in the Primary Health Care clinical practice field One of the most characteristic ways in which burnout is manifested is in the development of low morale, resulting in negative attitudes (Muldary 1983:90). This is apparent in responses such as:

'Some PHC nurses [PCNs] are not interested in their own job, therefore will not mentor learners.'

'The sisters [PCNs] refuse to help you [...].'

Hamilton (1996:325) describes morale as an attitude that people have towards their work. If morale is low, people's discouragement shows itself in a negative attitude and reduced effort and efficiency in work performance; thus preceptors are not interested in their own work or in mentoring students.

Lack of recognition, support and incentive for preceptors

Our findings indicated that preceptors believe they do not get recognition and support from management in the PHC clinical practice field, as observed in these comments:

'PHC nurses [PCNs] do not get support from management.'

'We [PCNs] do a lot of work, so definitely, we really need to be recognised.'

'PHC nurses [PCNs] are not recognised unless they've made a mistake.'

A lack of recognition, support and incentive can lead to low morale of staff, resulting in an overall reduction in clinical performance efficiency (Muldary 1983:68). Muldary (1983:154) further maintains that managers are usually inefficient in their recognition and appreciation of staff.

A study on preceptors' views and understanding of their mentoring role by Pulsford et al. (2002) established that the preceptors felt they did not have adequate support from their managers. Participants in the study under review also expressed the following:

'People are overworked in the clinics and yet there is no incentive.' 'In some institutions nurses are taken as a replacement for doctors and there is no incentive for that. Another problem, I think, is the lack of promotion; if something [an incentive] could be created in primary health care structure.'

Some employees regard a paycheque as a 'scorecard' which indicates how well they are performing and feel that a higher salary symbolises recognition, reward and reaffirmation of worth (McConnell 2004:100, 101).

\section{Lack of quality control in the Primary Health Care clinical practice field}

The results indicate that there was lack of quality control in the PHC clinical practice field when participants mentioned that:

'There is no quality control or very little in the clinics.'

'Bad clinical practices are never addressed in the clinics.'

'There's different standards out where we're actually working.'

Quality control is an important aspect of caring within the nursing profession and $\mathrm{PCN}$ as practitioners (and preceptors) are required to put a high premium on ensuring quality patient care (Muller 2002:200). Lack of quality control is reported as a lack of continuing education, lack of feedback, lack of appropriate qualifications and lack of adequate staffing.

\section{Lack of continuing education for preceptors}

Lack of continuing education for PCNs who are preceptors for students was mentioned as one the reasons why they (preceptors) did not have adequate or updated clinical knowledge and skill to guide the students in the PHC clinical fields:

'PHC nurses $[\mathrm{PCNs}]$ do not go for updating and they will always give us old information at the practicals.'

In the report by Pulsford et al. (2002), preceptors were often not able to attend update sessions due to staff shortages or due to 
lack of information about the available sessions of continuing education by management.

Lack of feedback from preceptors and from referral resources

Participants also voiced their concerns about a lack of feedback from the preceptors and from other resources like the hospital, physiotherapy and other relevant referral resources:

'We never get feedback from referral resources - feedback makes people more competent.

Feedback helps in rectifying your own clinical mistakes and perfecting your knowledge and skill. Wong et al. (2004) confirmed the lack of feedback by establishing in their study that fewer than half of the preceptors provided feedback to students routinely.

\section{Preceptors' lack of appropriate qualifications}

The study results showed that some of the preceptors did not have the required qualification to be preceptors and thus could not improve the students' clinical competencies, as observed by one of the student participants:

'Some mentors [preceptors] have only basic nursing with community nursing and do not have skills of PHC.'

Andrews and Chilton (2000:555-556) explain that the clinical experience of preceptors who lack appropriate qualifications does not fully compensate for the lack of clinical and theoretical knowledge of the student, and therefore cannot adequately develop the clinical competencies of students. The appropriate clinical knowledge and skills help to prepare and support the preceptor for the role of mentoring (McCarty \& Higgins 2003).

\section{Lack of adequate staffing}

A lack of adequate staffing can lead to nurses employing poor clinical practices, as indicated in this statement:

'The seniors [preceptors] do shortcuts, while you still need the right thing to be guided in, and you still find yourself incompetent in most of the things [clinical knowledge and skill].

A shortage of nursing personnel creates a crisis for quality health care and affects patient outcomes (Jackson et al. 2002). This finding is in keeping with that of Boswell, Lowry and Wilhoit (2004), who claim that one of the best ways to ensure quality is to have adequate and competent nursing staff (refer also to the section on 'Shortage of staff').

\section{LIMITATIONS OF THE STUDY}

Only clinical instructors and students following the learning programme participated in the study. The preceptors in the PHC clinical practice field, who spent most of the time with the student in the PHC clinical practice field, did not participate in the study because of difficulties experienced by the researcher with regard to travelling arrangements (e.g. distance) and accessibility to defferent PHC clinical practice fields (clinics).

\section{RECOMMENDATIONS}

It is recommended that managers within the PHC clinical practice field ensure adequate staffing and the availability of suitable clinical equipment in good working condition. This will enable PCNs to do their clinical work efficiently and to instruct students appropriately.

It is also recommended that managers maintain quality patient care in the PHC clinical practice field by ensuring the availability of continuing education and that PCNs attend these sessions in order to have and maintain up-to-date clinical knowledge and skill in clinical protocols. This in turn, will result in effective instruction guidelines in terms of developing students' clinical competencies.

The researchers recommend establishing structured collaborative relationships and formal partnerships between the PHC clinical practice field and the university. This is to ensure that clinical care and educational outcomes are achieved, including quality control in terms of proper qualifications, recognition and incentives for clinical instructors and preceptors in the PHC clinical practice field. This will result in increased morale, improved support for students and subsequent improvement in clinical competencies.

The researchers recommend that further research be done on the perceptions of preceptors in the PHC clinical practice field regarding reasons for students' poor clinical competencies and/ or on their needs as preceptors, in order to ensure effective and efficient mentoring of students within the $\mathrm{PHC}$ clinical practice field.

\section{CONCLUSION}

We report on the reasons for poor clinical competencies of students after 2 years of participation in the PHC: Clinical Nursing, Diagnosis, Treatment and Care programme, despite the supervision, guidance and instruction within the PHC clinical practice field offered by both instructors and preceptors. It is important for students to be clinically competent so as to be able to meet the need 'to function independently as a frontline provider of clinical PHC services within the public PHC facilities' (DoH 1996:18). The primary factor responsible for students' poor clinical competencies is their lack of clinical practice in the PHC clinical practice field. Several reasons for this were expressed by participants (i.e. clinical instructors and students) during focus group interviews.

\section{SUMMARY OF THE RESULTS}

Theme 1 of perceived challenges within the Primary Health Care clinical practice field, reasons contributing to students' poor clinical competencies can therefore be summarised as follows.

Lack of human and material resources in the Primary Health Care clinical practice field

- Shortage of staff.

- Students regarded as part of staff (i.e. as part of workforce).

- Lack of clinical equipment and other relevant resources.

\section{Staff burnout in the Primary Health Care clinical practice field \\ - Low morale and negative attitude of preceptors and staff. \\ - Lack of recognition, support and incentive for preceptors.}

Lack of quality control in the Primary Health Care clinical practice field

- Lack of continuing education for preceptors.

- Lack of feedback from preceptors and from referral resources like the hospital.

- Lack of appropriate qualifications by preceptors.

- Lack of adequate staffing.

The factors underlying poor clinical competencies of students in the programme provide the basis for proposed guidelines to improve clinical competencies of students, which are presented in a separate article.

\section{REFERENCES}

Andrews, M. \& Chilton, F., 2000, 'Student and mentor perceptions of mentoring effectiveness', Nurse Education Today 20, 555-562

Atkins, S. \& Williams, A., 1995, 'Registered nurses' experience of mentoring undergraduate nursing students', Journal of Advanced Nursing 21, 1006-1015. 
Beukes, K., 1983, 'Why PHC? And Some Pertinent Problems Associated With It', paper presented at an exploratory meeting, arranged by the Director of Hospital Services, Gauteng (then Transvaal), to discuss the introduction of PHC to all the hospitals in the then Transvaal and the problems associated with it. The management of all hospitals in Transvaal were present, Kalafong Hospital, Gauteng, n.d.

Bezuidenhout, C., 2003, 'Guidelines for enhancing clinical supervision', Health SA Gesondheid 8(8), 12-23.

Boswell, S., Lowry, L.W. \& Wilhoit, K., 2004, 'New nurses' perception of nursing practice and quality patient care', Journal of Nursing Care Quality, (abstract), vol. 19(1), 76, viewed 03 March 2005, from www.proquest.umi.com.raulib. rau.ac.za

Burns, N. \& Grove, S.K., 2001, The Practice of Nursing Research: Conduct, Critique and Utilization, W.B. Saunders, Philadelphia.

Cilliers, F., 2003, 'Burnout and salutogenic functioning of nurses', Curationis May, 26, 62-74. Creswell, J.W., 1994, Research Design: Qualitative and Quantitative Approaches, Sage, California

Creswell, J.W., 2003, Research Design: Qualitative, Quantitative and Mixed Method Approaches, 2nd edn., Sage, California.

Department of Health, 1996, Restructuring the National Health System for Universal Primary Health Care, Pretoria.

Department of Health, 1999, South African Health Sector Strategic Framework of 1999-2004, Pretoria.

Department of Health, 2001, A Comprehensive Primary Health Care Service Package for South Africa, Pretoria.

De Vos, A.S., 2001, Research at Grass Roots. A Primer for the Caring Profession, Van Schaik, Pretoria.

Edwards, H., Smith, S., Courtney, M., Finlayson, K. \& Chapman, H., 2004. 'The impact of clinical placement location on nursing students' competence and preparedness for practice', Nurse Education Today, (abstract), vol. 24(4), 248-255, viewed 15 December 2004, from www.sciencedirect.com.raulib.rau. ac.za

Ehlers, V.J., Oosthuizen, M.J., Bezuidenhout, M.C., Monareng, L.V. \& Jooste, K., 2003, 'Post-basic nursing students' perceptions of the emigration of nurses from the RSA', Health SA Gesondheid 8(4), 24-37.

Hamilton, P.M., 1996, Realities of Contemporary Nursing, AddisonWesley, California.

Jackson, M., Chiarello, L.A., Gaynes, R.P. \& Gerberding, J.L. 2002, 'Nurse staffing and health care-associated infections', Proceedings from a working group meeting: American Journal of Infection Control June, 30(4), 199-206.

Kyrkjebo, J.M. \& Hage, I., 2004, 'What we know and what they do: nursing students' experiences of improved knowledge in clinical practice', Nurse Education Today 25(3), 167-175.

Law, M., 2000, 'Managing quality of teaching and learning in the ophthalmic nursing course', Nurse Education Today, (abstract), vol. 20(2), 136-140, viewed 10 March 2005, from www.sciencedirect.com.raulib.rau.ac.za

Lincoln, V.S. \& Guba, E.G., 1985, Naturalistic Enquiry, Sage, California.

McCarty, M. \& Higgins, A., 2003, 'Moving to an all graduate profession: Preparing preceptors for their role,' Nurse Education Today 23(2), 89-95, viewed 15 December 2004, from www.sciencedirect.com
McConnell, C.R., 2004, Managing the Health Care Professional, Jones and Bartlett, Canada.

Mofukeng, D.B., 1998, Acceptability of Clinical Community Nursing Skills in Mobile Health Services, Rand Afrikaans University, Department of Nursing.

Monamodi, S.S., 1998, Perceptions of Health Assessment, Treatment and Care by Community Nurses, Rand Afrikaans University, Department of Nursing.

Morolong, B.G., 2002, Competency of the Newly Qualified Registered Nurse from a Nursing College, Rand Afrikaans University, Department of Nursing.

Morton-Cooper, A., \& Palmer, A., 2000, Mentoring, Preceptorship and Clinical Supervision - A Guide to Professional Support Roles in Clinical Practice, 2nd edn., Blackwell, Oxford.

Muldary, T.W., 1983, Burnout and Health Professionals: Manifestations and Management, Capistrano, California.

Muller, M., 2002, Nursing Dynamics, 3rd edn., Heinemann, Sandton.

Polit, D.F. \& Hungler, B.P., 1995, Nursing Research: Principles and Methods, J.B. Lippincott, Philadelphia.

Pulsford, B.A., Bolt, K. \& Owen, S, 2002, 'Are mentors ready to make a difference? A survey of mentors' attitude towards nurse education', Nurse Education Today, (abstract), vol. 22(6), 439-44, viewed 15 December 2004, from www.sciencedirect. com.raulib.rau.za

Rand Afrikaans University, 2002, Department of Nursing - PHC: Clinical Nursing,Diagnosis, Treatment and Care, Study Guide, Johannesburg.

Rossouw, D., 2000, Intellectual Tools - Skills for Human Sciences, Amabhuku, Pretoria.

South Africa (Republic), 1978, Nursing Act, No. 50 of 1978, Government Printer, Pretoria.

South African Nursing Council, 1984, Regulations relating to the Keeping, Supply, Administering or Prescribing of Medicines by Registered Nurses, Government Notice R1248, viewed 03 April 2003, from www.sanc.co.za/regulat/Reg-med.htm

South African Nursing Council, 1997, Regulation for the diploma in Clinical Nursing Science, Health Assessment, Treatment and Care, Government Notice R71, viewed 03 April 2003, from www.sanc.co.za/regulat/Reg-cht.htm

South African Qualifications Authority, 2000, SAQA Bulletin, Government Printer, Pretoria.

Thwala, F.N., 1999, Midwives' Experience of their Clinical Education at a Nursing College in Swaziland, Rand Afrikaans University, Johannesburg.

World Health Organization, Department of Non-Communicable disease, prevention and health promotion, 1978, Declaration of Alma-Ata, viewed 04 April 2003, from, http://www.who. int/hpr/backgroundhp/almaata.htm

World Health Organization, 1978, Primary Health Care, Report of the International Conference on PHC, Alma Ata, USSR, Geneva.

Wong, V., Millen, B.E., Geller, A.C., Rogers, A.E., Maury, J. \& Prout, M.N., 2004, 'What's in store for medical students? Awareness and utilization of expert nutrition guidelines among medical school preceptors', Prevention Medicine 39(4) 753-759, viewed 16 March 2004, from www.sciencedirect. com.raulib.rau.ac.za

Zondagh, C., 2004, 'Safe and adequate nurse staffing', Nursing Update 28(5), 20-24. 